\title{
Fatal attraction: inheritance and collostruction in the ihjel-construction
}

\author{
Kim Ebensgaard Jensen \\ The purpose of this paper is two-fold. Firstly, it presents an argument \\ for usage-based inheritance models over complete inheritance mo- \\ dels in construction grammar. It is argued that, with the principle of \\ inductive language learning as their foundation, usage-based inheri- \\ tance models allow for redundancies and incongruities in construc- \\ tion networks which enables linguists to take into account details of \\ language use, which would otherwise not be facilitated in complete \\ inheritance models. Secondly, making use of the method of collo- \\ structional analysis, the article offers a corpus-based description of \\ the use of the Danish ihjel-construction which accounts for patterns \\ of attraction of construction-verb attraction, patterns of productivity, \\ and various types of subconstructions, including item- and item- \\ class-based ones and metaphorical extensions. The description of \\ the ihjel-construction should also illustrate the superiority of usage- \\ based inheritance models over complete inheritance models in con- \\ struction grammar-based language description.
}

\section{Introduction}

The Danish adverbial particle ihjel appears to be deceptively simple, which is probably why it has received extensive attention by neither syntacticians nor lexicologists, and in-depth analyses and descriptions are few and far between.

Its formal simplicity is striking. It seems to exclusively enter into two-word phrasal verb constructions. However, while formally simple, it is much more complicated functionally, as it covers a wide range of different functions. In some cases, like brcende ihjel ${ }^{1}$ or tceve ihjel, the verb-plus-ihjel constellation quite literally expresses a situation in which a specific action specified by the verb - in this case, the actions of setting someone afire and of beating someone severely up - results in the death of this someone. But in other cases, as in the case of sla ihjel, 
the constellation does not predicate any specific action but rather just the killing of someone in general. There are also cases in which ihjel combines with verbs that cannot possible result in anyone's death as in kede ihjel or skygge ihjel. In some cases, despite all logical improbabilities, the instance will refer to a literal death, but in other instances to a metaphorical one. Moreover, ihjel does not indiscriminately appear with any verb at any time. If one were to observe ihjel in use, one would find that certain verbs and verb types are much more frequent with ihjel than others, and that there seem to be certain patterns in the relation of attraction and repulsion between verbs and ihjel. A question that will doubtlessly arise from such an observation is whether there is any form of item correlation between verb attraction and communicative functions of ihjel.

Another question is how to best describe this phenomenon. Since ihjel conventionally enters into phrasal verb-like constellations in present-day Danish, and rarely appears on its own, a reasonable assumption, in a functional-cognitivist perspective, would be that the verbplus-ihjel constellation is a construction and, consequently, it would be appropriate to describe it in a construction grammar framework. But that would not be enough, one would also have to consider how to account for the relations between the construction and its instances in discourse; that is, one would have to apply an appropriate model of inheritance in the constructionist description of ihjel.

This paper presents an empirical constructionist study of the combination of verbs and the particle ihjel. While empirically based on three hypercorpora, the description of the ihjel-construction presented here should not be taken to be any form of exhaustive and final description of ihjel. Rather, it should be seen as a first step towards a constructionist description of the construction, exploring the descriptive possibilities of a usage-based approach, in which the construction is an asymmetric category which subsumes different types of subsets - with differing degrees of entrenchment and idiomaticity as well as differences in symbolic structure and patterns of use - as opposed to a description based on complete inheritance, in which a construction is a symmetric category which does not account for differences among its instances.

Before exploring the ihjel-construction itself, we will briefly introduce construction grammar in section 2 which serves as the theoretical framework of our discussion of the construction, and, in section 3 , we shall contrast usage-based inheritance with complete inheritance pointing out the advantages of the former in the description of the ihjel- 
construction. After a brief overview of the data and method in the fourth section, verb attraction in the ihjel-construction in general is discussed in the light of the results of the corpus investigation in section 5 . In section 6, we will look specifically at the symbolic and conventional status of the specific combination of the verb sla and ihjel, arguing that it serves a specific communicative purpose of its own, and section 7 deals with instances of the ihjel-construction co-occurring with reflexive subject exploring the possibility that this constellation might subsume a number of verb-class-based extensions. Finally, in section 8 , we discuss metaphorical extensions of the construction.

\section{Constructions}

The theoretical framework of the present study is that of construction grammar (Goldberg 1995; Fillmore, Kay \& O’Connor 1998; Croft 2001) in which the concept of construction is the central unit of grammar. A construction is defined as "an entrenched routine ..., that is generally used in the speech community ... and involves a pairing of form and meaning" Croft (2005:274), and may be found at all levels of linguistic competence:

linguistic knowledge at all levels, from morphology to multi-word units can be characterized as constructions, or pairings of form and meaning ... language users exploit constructions at these various levels to discern from a particular utterance a corresponding collection of interrelated conceptual structures. (Bergen/Chang 2005: 145).

Constructions are conventionalized pairings of form and meaning and essentially semiotic units. Accordingly, rather than being two separate areas of linguistic competence, syntax and the lexicon form a continuum, referred to as the syntax-lexicon continuum (Goldberg 1995:7; Croft 2001:17).

As Lakoff (1977) points out, constructions are considered gestalts at several levels. A complex construction is a gestalt, such that the entire form is a templatic configuration which expresses semantic and pragmatic content. The formal elements of a construction are defined on the basis of the construction as a functional whole. The form of a construction may be substantive (lexically fixed) or schematic (lexically open). Substantivity/schematicity is essentially a matter of degree (Fillmore, Kay \& O'Connor 1988:505fn3) such that a continuum may be posed ranging from totally substantive constructions over constructions with

both substantive and schematic elements to constructions which are to- 
tally schematic (Croft \& Cruse 2004:233-234). Gestaltic features are also found at the semantic level of a construction. The content is often a complex matrix (Langacker 1987, 1991) of cognitive models, which are themselves conceptual gestalts. Consequently, the semantic components of a construction are defined on the basis of the cognitive models they are part of. Finally, the construction is a semiotic gestalt in that the form and content, being associated through convention, form a symbolically holistic structure. This means that the symbolic units within the construction are defined on the basis of the entire construction as a whole. The internal symbolic complexity differs from construction to construction, and constructions are not necessarily of a biunique symbolic nature since one element may form more than one symbolic unit and vice versa.

Since constructions are held to be gestalts, they are idiomatic to some degree. Idiomaticity is, indeed, considered central in the definition of the concept of a grammatical construction:

$\mathrm{C}$ is a construction $\operatorname{iff}_{\text {def }} \mathrm{C}$ is a form-meaning pair $<\mathrm{F}_{i}, \mathrm{~S}_{i}>$ such that some aspect of $\mathrm{F}_{i}$ or some aspect of $\mathrm{S}_{i}$ is not strictly predictable from C's component parts or from other previously established constructions. (Goldberg 1995:4)

However this does not mean that constructions are per se non-compositional. As Michaelis (1998:79) points out, "[t]he Construction Grammar approach does not deny the existence of compositionally derived meaning". Since many constructions may indeed be analyzed into symbolic units, it would make no sense to argue that construction grammar is a totally non-compositional approach to linguistic structure. Constructions may indeed be compositional, but as Lakoff (1987:465) argues, "grammatical constructions in general are holistic, that is, ... the meaning of the whole construction is motivated by the meanings of the parts but is not computable from them". The compositionality of a construction is thus determined by its inner symbolic structure. Constructions as well as their instances may differ from each other in terms of idiomaticity such that expressions that are semantically derived from their parts display low idiomaticity and those which are not display high idiomaticity. According to Lipka \& Schmid (1994), idiomaticity is very much a matter of degree, and constructions and instances may be plotted onto what they call the scale of idiomaticity. 
Constructions are organized in taxonomic networks in which a central schematic construction, providing the formal, semantic and symbolic configuration, licenses instances of the construction. The instances inherit the basic structural configuration from the central schema, much like prototype categories in general, and elaborate on the instance by specifying them lexically.

\section{Ihjel: structure and inheritance}

Ihjel is traditionally defined as an adverbial particle which expresses the semantic component TO DEATH, both in a literal sense, as in example (1), and in a metaphorical sense, as in (2):

\section{(1) De toevede ham ihjel.}

They beat him to death.

(2) Han kedede sig ihjel.

He was bored "to death".

According to ODS (2007), the adverbial particle ihjel is ultimately derived from the Old Danish expression $i$ hel (or $i$ hoel), which literally means INTO THE REALM OF DEATH. Thus ihjel seems to have undergone the grammaticalization process of condensation in which larger multiunit structures are contracted and condensed into smaller structures of fewer units (Croft 2000:158). Although this is a discussion I shall not pursue further, it could be argued that in the case of ihjel, condensation is actually a lexicalization process, as ihjel might be argued to be a lexical semantic particle which primarily contributes lexical meaning to the constructional verb-plus-ihjel complex.

In Modern Danish, ihjel mainly enters into phrasal verb relations which predicate actions that result in the literal or metaphorical death of one or more participants in the situation described. The verb expresses the action itself, and ihjel specifies that the action has fatal consequences:

(3) Ericson måtte dolke ham ihjel, da vennen var ved at telefonere sine oplysninger.

Ericson had to stab him to death, as the friend was about to phone in the information.

(4) Gud lader folk sulte ihjel.

God lets people starve to death. 


\section{Kim Ebensgaard Jensen}

(5) Før Pickles hakker ham ihjel, springer en tilskuer ind i arenaen. Before Pickles can peck him to death, a spectator jumps into the arena.

(6) På vejen fryser hun ihjel $i$ en snedrive.

On the way, she freezes to death in a snowdrift.

(7) Det vil sige, at folk her keder sig ihjel?

Does that mean that people around here are bored to death?

(8) Jeltsin er ved at drikke sig ihjel.

Jeltsin is drinking himself to death. = Jeltsin is killing himself through excessive alcohol consumption.

At first glance, it seems that, as a construction, the constellation of a verb-plus-ihjel has a rather simple symbolic structure, which, in a Langackerian $(1987,1991)$ fashion, may be represented as [[V ihjel]/ [ACTION RESULTING IN DEATH OF PARTICIPANT]] (or [[V ihjel]/[ACTION > DEATH]]). ${ }^{2}$

This constructional structure is essentially an atomic one in which there is a biunique relationship between form and content. The form consists of two elements - namely, the verb and ihjel - and the content of two components - namely, whatever ACTION the PARTICIPANTS are involved in and DEATH OF A PARTICIPANT (or TO DEATH for short) respectively. The action itself is specified by the verb through a process called elaboration which is the addition of further conceptual information to a schematic structure by filling a lexically open slot, a so-called elaboration site (or e-site), in a construction (Langacker 1987:304).

Thus, in example (5), the verb hakke specifies the action as that of PECKING (see appendix for a glossary of verbs) and ihjel indicates that the consequence of the pecking is the death of Pickles' victim. Likewise, in example (6), fryse specifies the action, which in this case is the situation of FREEZING, and ihjel indicates that the situation results in the DEATH of the primary participant.

The general symbolic structure of $[[\mathrm{V}$ ihjel $] /[\mathrm{ACTION}>\mathrm{DEATH}]]$ seems quite simple and could form the basis of a so-called complete inheritance taxonomy (Goldberg 1995:73-4; Croft \& Cruse 2004:2702 ), which is characterized by maximal generality, as all instances are directly licensed by one central abstract construction. According to Croft \& Cruse (2004:271), “[i]n a complete inheritance model, a construction can inherit the feature structures of its parent construction; this is 
the significance of the taxonomic relation between constructions in this model." This means that all information relating to the construction is stored in the abstract construction, and thus "complete inheritance is an all-or-none relation" (Croft \& Cruse 2004:271). In a complete inheritance model, dolke ihjel, sulte ihjel, hakke ihjel, fryse ihjel, kede ihjel, and drikke ihjel, are all direct instances of [[V ihjel]/[ACTION > DEATH]], and all of their formal and semantic properties can ultimately be traced back to this central abstract schematic construction.

This would be a simple and easy-to-grasp representation of the ihjel-construction, but, due to the all-or-nothing nature of complete inheritance models, it would ultimately be an imprecise one which would fail to capture several critical details regarding patterns of use.

Where complete inheritance models fail to capture details regarding patterns of use, a usage-based inheritance model would not only capture these but also allow for patterns of use to be distinctive such that recurring differences in use may serve as features of subconstructions within a more fine-grained constructional network. Different patterns of use, if statistically significant enough, may be entrenched (Langacker 1987:59) in the network with differing degrees of productivity and idiomaticity, as usage-based inheritance allows for category-instance discrepancies and for information redundancy throughout the taxonomy.

Usage-based models do not separate competence from performance since "structure, or regularity, comes out of discourse and is shaped by discourse in an ongoing process" (Hopper 1998:156). As Tomasello (2003:99) points out,

for usage-based theorists the fundamental reality of language is people making utterances to one another on particular occasions of use. When people repeatedly use the same particular and concrete linguistic symbols to one another in "similar" situations, what may emerge over time is a pattern of language use schematised in the minds of users as one or another kind of linguistic category or construction.

Grammar is not an inventory of preset rules and principles that govern linguistic interaction. On the contrary, linguistic competence emerges through discourse, and repetitions in discourse result in the storage of entrenched, but not infinitely fixed, schematizations which languageusers apply in discourse - both in decoding and encoding. This means that grammatical structures and lexical units alike are conventionalized through discourse. Thus, a language user's linguistic knowledge is ultimately experientially based on the frequency of usage-events (Kemmer \& Barlow 2000:ix). 


\section{Kim Ebensgaard Jensen}

The usage-based approach also rejects the notion of a completely decontextualized grammar. Context plays a crucial role in the operation of the linguistic system since language does not exist vacuously, but rather in the context of the world that its speakers live in (Kemmer \& Barlow 2000). All types of context may have an impact on the linguistic system to the point that contextual information can be entrenched as linguistic competence if a specific construction is highly frequent in a specific type of context or situation. Moreover, the usage-based approach takes as a central principle the interconnectedness between the linguistic system and non-linguistic cognitive systems such that language is an integrated part of general human cognition and subject to the same processes and principles.

Since linguistic competence is based on inductive learning, linguistic knowledge is acquired in a bottom-up manner through use, allowing for redundancy, generalizations, and types at all levels of the constructional taxonomy.

\section{Data and method}

The present study is based on an investigation of three Danish language corpora containing written texts - namely, Korpus 2000 (20 million words), Korpus 90 (20 million words), and DFK Loke (1 million words) - all of which are available in the Danish corpus section at VISL (2008). Korpus 2000 and Korpus 90 are mixed written corpora, the former covering texts from 1998 to 2002 and the latter texts from 1988 to 1992 (these two corpora are also available as one corpus, which is called Korpus DK and is available at the website of Det Danske Sprog- og Litteraturselskab), while DFK Loke contains texts from the online journal Loke. Using Bick's (2005) CorpusEye concordancer, all instances of ihjel were extracted from these corpora and subjected to qualitative and quantitative analyses.

All occurrences of the ihjel-construction were analyzed qualitatively and classified in terms of internal symbolic structures and association patterns. Association patterns are "the systematic ways in which linguistic features are used in association with other linguistic and non-linguistic features" (Biber, Conrad \& Reppen 1998:5; Biber 2000:289).

The primary quantitative analytical framework is that of collostructional analysis which is a collocational statistical method of measuring the attraction strength, or collostruction strength, between 
constructions and lexical items (Stefanowitsch \& Gries 2003). Collostruction strength is calculated on the basis of the frequency of the cooccurrence of item and construction, the frequency of the item in all other constructions, the frequency of the construction with all other constructions, and the frequency of all other items in all other constructions. These frequencies are then run through a Fischer exact test, a loglikelihood test or a similar test. This results in a so-called p-value which is a number that indicates the collostruction strength. The higher the number, the stronger the collostructional attraction. Every lexeme that appears in the construction in the corpus is subjected to this operation, and when this procedure has been applied to all lexemes, they are ranked in accordance with collostruction strength, the most attracted item ranking the highest. ${ }^{3}$

Attraction patterns may indicate the overall meaning of the construction. According to the principle of semantic compatibility "words can (or are likely to) occur with a given construction if (or to the degree that) their meanings are compatible" (Stefanowitsch \& Gries 2005:4). Thus, the meaning of the construction is likely to be closely related to the meanings of the lexemes that are attracted to it. Moreover, attraction patterns may serve as an indicator of entrenchment and productivity. If a lexeme, or a class of lexemes, is highly attracted to a construction, and the qualitative analysis shows that this particular lexeme-construction combination serves a specific communicative function, the combination is likely to form an entrenched and productive item-specific or item-class-specific subconstruction (Croft 2003:57-58, Tomasello 2003:178). ${ }^{4}$ On the other hand, if a series of many different items display low collostruction strength in relation to a construction, then this could be taken to indicate a more lexically schematic construction.

\section{Verb attraction in the ihjel-construction and semantic compati- bility}

The following tables present the results of the collostructional analyses. As mentioned above, they are ranked in terms of collostructional strength: the higher the attraction of a lexeme to the ihjel-construction, the higher it ranks: 


\section{Kim Ebensgaard Jensen}

Table 1: Collostruction strengths in Korpus 2000 (log-likelihood)

\begin{tabular}{|c|c|c|c|c|c|c|c|c|}
\hline Rank & Lexeme & Collostruction strength & Rank & Lexeme & Collostruction strength & Rank & Lexeme & Collostruction strength \\
\hline 1 & slå & 8162.05601192555 & 20 & piske & 16.8740982306803 & 39 & smadre & 7.0637382053432 \\
\hline 2 & tie & 199.450358428844 & 21 & ade & 14.8727230123619 & 40 & kvoele & 6.97686250249287 \\
\hline 3 & fryse & 198.239483062038 & 22 & slide & 14.6793621612037 & 41 & lure & 6.68028541969256 \\
\hline 4 & sulte & 133.403364470369 & 23 & intellektualisere & 14.6371654978307 & 42 & klemme & 6.4328195352845 \\
\hline 5 & hakke & 116.648936561994 & 24 & snakke & 14.5189916804893 & 43 & underholde & 6.11441939187072 \\
\hline 6 & stikke & 110.828369357678 & 25 & analysere & 13.9957454065328 & 44 & slabe & 5.92674677905053 \\
\hline 7 & tave & 97.1975286757167 & 26 & jokke & 12.6554904853644 & 45 & konkurrere & 5.68068989556783 \\
\hline 8 & trampe & 86.140823206168 & 27 & bide & 12.6146715021357 & 46 & anmelde & 5.65410253020507 \\
\hline 9 & drikke & 78.2248636465177 & 28 & torste & 11.2419726279742 & 47 & udpege & 4.3456698144217 \\
\hline 10 & kede & 66.011692062483 & 29 & stampe & 10.9787942623007 & 48 & grine & 4.22954973379484 \\
\hline 11 & køre & 55.1757439527594 & 30 & bagatellisere & 10.4606525214006 & 49 & traene & 3.84636996005127 \\
\hline 12 & brande & 46.3334465092385 & 31 & blende & 10.1775854670365 & 50 & producere & 3.49415153301083 \\
\hline 13 & mase & 45.6281022022941 & 32 & toeske & 9.08778739754057 & 51 & ryge & 3.34577728371367 \\
\hline 14 & sejre & 40.8929128366056 & 33 & skygge & 9.05002148824702 & 52 & skyde & 3.23182366182973 \\
\hline 15 & prygle & 39.3848388040098 & 34 & gabe & 8.85425960147172 & 53 & synge & 3.0269751458824 \\
\hline 16 & sparke & 33.0883378877951 & 35 & riste & 8.52697106223301 & 54 & spise & 2.23172999036071 \\
\hline 17 & dolke & 28.2025942776285 & 36 & knokle & 7.64857021486806 & 55 & forklare & 1.62471645747137 \\
\hline 18 & stene & 26.6593023300169 & 37 & forurene & 7.3266177680155 & 56 & arbejde & 0.593507520358105 \\
\hline 19 & pine & 20.1646816245358 & 38 & beskatte & 7.0637382053432 & 57 & $g a ̊$ & 0.415735573463915 \\
\hline
\end{tabular}

Table 2: Collostruction strengths in DFK Loke (log-likelihood)

\begin{tabular}{|c|c|c|c|c|c|c|c|c|}
\hline \multicolumn{3}{|c|}{ Rank Lexeme Collostruction strength } & \multicolumn{2}{|c|}{ Rank Lexeme } & \multirow{2}{*}{$\begin{array}{l}\text { Collostruction strength } \\
14.2346629996570\end{array}$} & \multirow{2}{*}{$\frac{\text { Rank }}{11}$} & \multirow{2}{*}{$\begin{array}{l}\text { Lexeme } \\
\text { brande }\end{array}$} & \multirow{2}{*}{$\begin{array}{l}\text { Collostruction strength } \\
7.50490074603736\end{array}$} \\
\hline 1 & slå & 815.058594354556 & 6 & drikke & & & & \\
\hline 2 & fryse & 65.6469085654449 & 7 & pine & 11.8304916469021 & 12 & traede & 7.03958933861897 \\
\hline 3 & kede & 26.6236711574002 & 8 & slikke & 11.4005562931867 & 13 & stikke & 6.88847490853587 \\
\hline 4 & sulte & 21.6130382833026 & 9 & trampe & 9.7460503141066 & 14 & kфre & 5.09263122772377 \\
\hline 5 & tie & 19.2458253534347 & 10 & banke & 8.37937144001698 & 15 & ligge & 3.33135969258534 \\
\hline \multicolumn{9}{|c|}{ Table 3: Collostruction strengths in Korpus 90 (log-likelihood) } \\
\hline Rank & $\mathrm{k}$ Lexeme & e Collostruction strength & h Rank & Lexeme & Collostruction strength & Rank & Lexeme & Collostruction strength \\
\hline 1 & slå & 10173.1858047602 & 22 & køre & 24.2465208960621 & 43 & koge & 7.50559453221148 \\
\hline 2 & sulte & 325.039945061079 & 23 & stene & 24.0276901721085 & 44 & gabe & 7.30424626446928 \\
\hline 3 & tie & 181.363880476417 & 24 & taerske & 23.8172623602923 & 45 & svede & 6.53157514345278 \\
\hline 4 & stikke & 178.378566264311 & 25 & prygle & 22.8243221529522 & 46 & riste & 6.3441096923247 \\
\hline 5 & fryse & 176.159771340086 & 26 & traede & 18.9015585683915 & 47 & konkurrere & 5.68719158906328 \\
\hline 6 & drikke & 117.058952036521 & 27 & trampe & 17.0993969584021 & 48 & vokse & 5.67909629199282 \\
\hline 7 & brande & 105.322525730640 & 28 & grine & 15.6984988110873 & 49 & tale & 5.5009489136288 \\
\hline 8 & kede & 93.6647069419159 & 29 & spare & 14.7458288605423 & 50 & tvivle & 5.44475649394423 \\
\hline 9 & bide & 75.339150092912 & 30 & sфrge & 12.8346214635144 & 51 & hygge & 5.33967854489175 \\
\hline 10 & tave & 71.2730283200295 & 31 & piske & 11.8664096764299 & 52 & ade & 4.7304451663754 \\
\hline 11 & stange & 51.8657388157762 & 32 & hakke & 11.4027146282575 & 53 & slace & 4.53518671815439 \\
\hline 12 & sparke & 40.9902014029278 & 33 & $s \phi d e$ & 9.9298604419723 & 54 & skylle & 4.48827452716858 \\
\hline 13 & dolke & 40.7106195449221 & 34 & torste & 9.9298604419723 & 55 & banke & 4.04972774555123 \\
\hline 14 & klemme & 32.8039757120755 & 35 & torturere & 9.5193221628498 & 56 & klippe & 3.65887041240696 \\
\hline 15 & slide & 30.2732529343940 & 36 & skolde & 9.48864971587203 & 57 & ligge & 2.98686014786708 \\
\hline 16 & knokle & 30.1882927589069 & 37 & fortie & 9.10260175016722 & 58 & diskutere & 2.78336114148469 \\
\hline 17 & snakke & 29.3987615317089 & 38 & profilere & 9.10260175016722 & 59 & producere & 2.74379608710574 \\
\hline 18 & pine & 28.1175419050638 & 39 & danse & 8.79986294001278 & 60 & behandle & 2.06882148380361 \\
\hline 19 & skygge & 28.0889310274552 & 40 & gasse & 8.75838232088111 & 61 & elske & 1.53667947029449 \\
\hline 20 & skyde & 27.6855239595325 & 41 & snappe & 8.65575579578244 & 62 & spise & 1.36037837809365 \\
\hline 21 & sejre & 25.9733323769132 & 42 & visne & 8.01254335972681 & 63 & sporge & 0.394057859441692 \\
\hline
\end{tabular}


The collostructional analyses indicate a preference for verbs that express violent actions that typically result in physical harm, damage or injury, such as hakke, sparke, stikke, tove, dolke, stene, prygle and pine, all of which are fairly strongly attracted to the ihjel-construction. Other verbs of violence such as piske, tceske, bide, kvcele, stange, and skyde as well as verbs that express other situations which are not necessarily violent, but certainly may result in physical harm, such as broende, skolde, koge, klemme, and rive, appear with varying degrees of attraction. Below are some examples of verbs of violence and direct or indirect harm in the ihjel-construction - see also (1), (3), and (5) above:

(9) De sparkede dem ihjel, mand!

They kicked them to death, man!

(10) Når en okse stanger en mand eller kvinde ihjel, skal oksen stenes, og man må ikke spise dens kød.

When an ox gores a man or a woman to death, it must be stoned and eating its flesh is forbidden.

(11) Og kapitlet ender endda med, at de jøder, han har snakket med, - altså de, der var kommet til at tro på ham, - ta'r sten op og vil stene ham ihjel, men han går sin vej.

And the chapter even ends with the Jews he spoke to - that is, those who had started to believe in him - picking up stones and wanting to stone him to death, but he walks away.

(12) Da en ukrainer så, at han lå på jorden og stadig trak vejret, blev han pryglet ihjel.

When a Ukrainian saw that he was still breathing, while lying on the ground, he was flogged to death.

(13) Man er blevet pisket ihjel.

One has been whipped to death.

(14) Og så er der indvandreren, der noesten toeskes ihjel af bøller, mens folk ved et stoppested overfor blot ser passive til. And then there's the immigrant who's almost being beaten to death by hooligans while people at a bus stop across the street just passively look on. 
Og der er såvel folkelig som retslig forståelse for, at politiet $i$ ny og nce må skyde en flygtning ihjel.

And there is public, as well as legal, understanding that the police have to shoot dead a refugee now and then.

It is no surprise that such verbs are highly attracted to the ihjel-construction, since one potential result of bodily harm caused by violence is death. The elaboration process is quite straightforward. Each verb expresses a scenario in which an ASSAILANT attacks a VICTIM which results in PHYSICAL HARM. Argument structure is important here, since the argument structure associated with the verbs in question express specific participant roles in the scenario. Most of the verbs of violence that appear in the ihjel-construction are transitive, the subject expressing the assailant and the object expressing the victim. When a verb of violence fills the verb slot in the ihjel-construction, the [SUBJ VVIOLENCE OBJ] structure specifies that the action of the verb in the ihjel-construction is a two-participant one in which the AGENTIVE participant fuses with the ASSAILANT, and the PATIENT with the VICTIM. The ACTION itself fuses with the situation expressed by the verb of violence, while the nature of the BODILY HARM is specified as being the DEATH of the VICTIM through ihjel. It is worth mentioning that the ihjel-construction, with some systematic exceptions, primarily appears in transitive contexts in the three corpora. A distinctive collexeme analysis, a type of collostructional analysis which measures the differences in attraction between one item and two or multiple functionally overlapping constructions (Gries \& Stefanowitsch 2004), has shown that that most verbs in the ihjel-construction appear with transitive and transitive-based constructions such as passive constructions and the antipassive construction (note that the ocurrence of identical collostruction strength numbers is caused by identical frequencies of cooccurrence): 
Fatal attraction: inheritance and collostruction ...

Table 4: Cross-corpora distribution of preferred transitivity contexts (T-contexts)

\begin{tabular}{|c|c|c|c|c|c|}
\hline Lexeme & T-context & Collostruction strength & Lexeme & T-context & Collostruction strength \\
\hline fryse & Intransitive & 160.330841244883 & konkurrere & Transitive & 0.139261693383262 \\
\hline sulte & Intransitive & 104.989168594515 & producere & Transitive & 0.139261693383262 \\
\hline brænde & Intransitive & 30.3784467423641 & riste & Transitive & 0.139261693383262 \\
\hline tørste & Intransitive & 13.5654294644269 & slæbe & Transitive & 0.139261693383262 \\
\hline visne & Intransitive & 6.76687243164386 & spise & Transitive & 0.139261693383262 \\
\hline koge & Intransitive & 4.062791251085 & tærske & Transitive & 0.139261693383262 \\
\hline slå & Transitive & 180.5046883491 & vokse & Transitive & 0.139261693383262 \\
\hline stikke & Transitive & 2.53096069854406 & anmelde & Transitive & 0.0696112944970866 \\
\hline tie & Transitive & 2.45995409784529 & arbejde & Transitive & 0.0696112944970866 \\
\hline drikke & Transitive & 1.96404326423250 & bagatellisere & Transitive & 0.0696112944970866 \\
\hline køre & Transitive & 1.32934433591839 & behandle & Transitive & 0.0696112944970866 \\
\hline kede & Transitive & 1.18874027602151 & beskatte & Transitive & 0.0696112944970866 \\
\hline tæve & Transitive & 0.908009597587837 & blende & Transitive & 0.0696112944970866 \\
\hline hakke & Transitive & 0.837926132439357 & diskutere & Transitive & 0.0696112944970866 \\
\hline bide & Transitive & 0.7678822593837 & elske & Transitive & 0.0696112944970866 \\
\hline trampe & Transitive & 0.697877933708995 & fortie & Transitive & 0.0696112944970866 \\
\hline snakke & Transitive & 0.627913110776946 & gasse & Transitive & 0.0696112944970866 \\
\hline sparke & Transitive & 0.627913110776946 & gå & Transitive & 0.0696112944970866 \\
\hline sejre & Transitive & 0.488101794973087 & hygge & Transitive & 0.0696112944970866 \\
\hline pine & Transitive & 0.418255213204187 & intellektualisere & Transitive & 0.0696112944970866 \\
\hline skyde & Transitive & 0.418255213204187 & jokke & Transitive & 0.0696112944970866 \\
\hline slide & Transitive & 0.418255213204187 & klippe & Transitive & 0.0696112944970866 \\
\hline dolke & Transitive & 0.348447956384181 & kvæle & Transitive & 0.0696112944970866 \\
\hline klemme & Transitive & 0.348447956384181 & lure & Transitive & 0.0696112944970866 \\
\hline prygle & Transitive & 0.348447956384181 & profilere & Transitive & 0.0696112944970866 \\
\hline træde & Transitive & 0.348447956384181 & ryge & Transitive & 0.0696112944970866 \\
\hline grine & Transitive & 0.278679980252553 & skolde & Transitive & 0.0696112944970866 \\
\hline knokle & Transitive & 0.278679980252553 & skylle & Transitive & 0.0696112944970866 \\
\hline ligge & Transitive & 0.278679980252553 & slikke & Transitive & 0.0696112944970866 \\
\hline mase & Transitive & 0.278679980252553 & smadre & Transitive & 0.0696112944970866 \\
\hline piske & Transitive & 0.278679980252553 & snappe & Transitive & 0.0696112944970866 \\
\hline skygge & Transitive & 0.278679980252553 & spørge & Transitive & 0.0696112944970866 \\
\hline stange & Transitive & 0.278679980252553 & stampe & Transitive & 0.0696112944970866 \\
\hline stene & Transitive & 0.278679980252553 & svede & Transitive & 0.0696112944970866 \\
\hline spare & Transitive & 0.208951240622732 & synge & Transitive & 0.0696112944970866 \\
\hline sørge & Transitive & 0.208951240622732 & søde & Transitive & 0.0696112944970866 \\
\hline tale & Transitive & 0.208951240622732 & tortere & Transitive & 0.0696112944970866 \\
\hline æde & Transitive & 0.208951240622732 & træne & Transitive & 0.0696112944970866 \\
\hline analysere & Transitive & 0.139261693383262 & tvivle & Transitive & 0.0696112944970866 \\
\hline banke & Transitive & 0.139261693383262 & tæske & Transitive & 0.0696112944970866 \\
\hline danse & Transitive & 0.139261693383262 & udpege & Transitive & 0.0696112944970866 \\
\hline gabe & Transitive & 0.139261693383262 & underholde & Transitive & 0.0696112944970866 \\
\hline
\end{tabular}


It is interesting to note that, while outnumbered by far by verbs in transitive constexts, the six verbs that prefer intransitive contexts in this construction yield higher numbers than any other verb with the exception of sla. A tentative explanation could be that they form a subset of their own which deviates in transitivity from the majority of the instances of the ihjel-construction. Some of the verbs certainly seem to be semantically related in terms of agency and other force dynamic relations. Verbs like fryse, sulte, tørste and visne all predicate situations in which some force, which is not identical to the primary participant, causes the primary participant to undergo a slow change of state which, due to the presence of ihjel, leads to the primary participant's ceasing to exist. They are not exactly verbs of violence, but they do result in some harm to the primary participant. It could be that the presence of such a force is simply implicit in the verbs to such an extent that it does not need to be overtly expressed through cooccurrence with a transitive argument construction. A similar explanation might apply to broende and koge which also predicate situations where some force leads to the destruction of the primary partitipant, the difference being that the predicated situations her eare less durative than with the four other verbs. If the implicitagency argument holds, then one might even take it a step further and argue that we are then dealing with a case of lexically expressed middle voice, which is the reason why these six verbs in the ihjel-construction are so strongly attracted to intransitive contexts.

In addition to verbs of violence, the ihjel-construction also attracts verbs that express situations which, if they involve animate participants, result in physical harm:

(16) Efterretningsforlydender vil vide, at lokale myndigheder og hoerenheder samarbejdede om at entre turisternes båd, tømme lommerne på dem, stoppe dem ned i bådens nederste kahyt og brcende dem ihjel.

According to intelligence reports, local authorities and militias cooperated in boarding the tourists' boat, emptying their pockets, stuffing them into the lowest cabin and burning them to death.

(17) Under de frygteligste pinsler blev den 87-årige Anne Pedersen natten til onsdag skoldet ihjel i sin seng på Sceby Aldrecenter. Suffering the most terrible torment, the 87-year-old Anne Pedersen was scalded to death in her bed in Sæby Resthome Tuesday night. 
Fatal attraction: inheritance and collostruction ...

(18) Anonyme mennesker, skummende af ondskab, proklamerer, at de kun ønsker at koge mig ihjel i kogende salpeter, udtalte Elsa Gress over seks spalter på BT's forside.

Anonymous people, foaming with evil, claim that all they want is to boil me to death in boiling nitre, said Elsa Gress over six columns on the front page of $B T$.

(19) Klemt ihjel i mejetcersker.

Crushed to death in a harvester.

The elaboration process is more or less identical to that described above in relation to less ambiguous verbs of violence.

Another group of verbs that seem to adhere to the semantic compatibility principle are verbs such as sulte (and, less prominently, tørste) and fryse, which express various situations of discomfort which may also lead to the death of the primary participant:

(20) Ofre for trafikulykker på Storebaltsbroen kan fryse ihjel, hvis ikke de reddes hurtigt.

Victims of accidents on the Great Belt Bridge may freeze to death if they are not rescued quickly.

(21) Så var der igen en bescetning på ca. 100 svin, der pga. vanrøgt sultede og torstede ihjel.

Yet another stock of about 100 pigs starved and thirsted to death due to neglect. $=$ Yet another stock of about 100 pigs died from starvation and thirst due to neglect.

Note that, unlike the verbs of violence and potential physical harm, these verbs, when in the ihjel-construction, appear in an intransitive context. Accordingly, the predicated scenario is rather different from the two-participant situations mentioned above. In cases like this, the ihjel-construction expresses a one-participant scenario in which the participant is subjected to some type of DISCOMFORT resulting in the DEATH of the participant. As table 4 shows, the difference in transitivity patterns between this use of the ihjel-construction and the transitive uses discussed above suggests that there are two transitivity-based subtypes of the construction which differ in terms of the situation-types and, consequently, verb preference. 
Generally, verbs that do not easily fit into the picture, like konkurrere, elske, grine, skygge, and spørge, display low degrees of attraction, which also would adhere to the principle of semantic compatibility. However, as mentioned above, there are a number of verbs that seem to violate the principle of semantic compatibility such as tie, drikke, sejre, and køre, which are highly attracted to ihjel, again suggesting that ihjel-construction is more complex in terms of entrenchment and productivity than what a complete inheritance taxonomy could capture:

(22) Det kan godt vaere, at vi har sejret os ihjel.

It may well be that we have triumphed ourselves to death.

(23) Den unge sygeplejerske Winnie Holms sorgløse tilvorelse bliver brat slået i stykker, da hendes elskede halvbror, Kenneth Larsen, kører en kvinde ihjel i beruset tilstand.

The young nurse Winnie Holm's peacful life is abruptly shattered when her beloved halfbrother Kenneth Larsen hits and kills a woman while driving drunk.

(24) Vi tillader folk at drikke sig ihjel.

We allow people to drink themselves to death.

(25) Debatten ties ihjel.

The debate is hushed to death. = The debate is hushed into oblivion.

I will return to these later on, discussing the possibility of some of these

forming idiomatic subconstructions within the ihjel-construction, some of which are of a metaphorical nature. ${ }^{5}$

\section{Slå ihjel: an idiomatic subconstruction}

In all of the above examples, the verb retains its basic meaning and contributes, through elaboration, to the final specification of the situation in question. However, interestingly, the verb that displays the highest degree of attraction, slä, does not retain its literal meaning in the ihjel-construction. Technically, slå is quite compatible with the ihjelconstruction and belongs to the group of verbs of violence. However, unlike what one might expect, slå ihjel does not mean HIT TO DEATH. Rather, it refers more generically to the act of KILLING or otherwise CAUSING someone TO DIE as illustrated by the following examples: 
Fatal attraction: inheritance and collostruction ...

(26) Han betragtede sin stivnede hånd, der dirrede svagt, få centimeter fra den rode plasticknap, der kunne afbryde den forbindelse, der slog ham ihjel.

He observed his stiffened hand, which was weakly shaking a few centimeters from the plastic button that could switch off the connection that was killing him.

(27) Heden kan slå os ihjel!

The heat can kill us!

(28) Når den hoevnende kanaima omsider finder den, der var skyld $i$ hans sloegtnings død, alene, kan han slå ham ihjel med kølle, pil eller gift.

When the avenging Kanaima finally finds the person who was responsible for the death of his relative, he may kill him with a club, an arrow or poison.

(29) Lokalbefolkningen fra landets to rivaliserende stammer slär hinanden ihjel med stokke, knive og macheter.

The locals from the country's two rivaling tribes kill each other with sticks, knives and machetes.

(30) Han hover sin jagtdolk og slår bjørnen ihjel, og den falder om ved hans fødder.

He raises his hunting dagger and kills the bear, and it drops dead at his feet.

(31) De mennesker, der slås ihjel af tobakken som midaldrende, ville i gennemsnit have haft yderligere 20-25 år, hvis de ikke havde røget.

Those people who are killed by tobacco as middle-ageds would have had further 20 or 25 years in average had they not been smokers.

The linguistic context indicates that, while the verb is slä, there is in fact no hitting involved. In (28) and (29), hitting may of course be involved since clubs and sticks are mentioned as possible weapons, but in either example such blunt weapons are only options among other non-blunt weapons, such as arrows and poison, in (28), and knives and machetes, in (29), and these non-blunt weapons certainly are legitimate 


\section{Kim Ebensgaard Jensen}

instruments in the actions slå ihjel predicates in (28) and (29). In (26), it predicates the situation of lethal electrocution, while in (27) it predicates the situation of dying from heat, and, in (31), it refers to death as the result of many years of smoking. Hitting is not, by any stretch of one's imagination, even potentially relevant to any of these situations. Instances like (26)-(31) indicate that the constellation slä-plus-ihjel is different from the instances in examples (1)-(25) in terms of the specificity of the action itself. In (1)-(25), a specific verb fills the verb position and, through elaboration, the combination of this specific verb and ihjel refers to a very specific fatal situation. Unlike the instances in examples (1)-(25), slå ihjel does not refer to a specific way of killing a participant in a situation, but to KILLING in general.

Thus, slå ihjel and [V ihjel] differ in terms of levels of categorization (e.g. Lakoff 1987). Sla ihjel expresses the basic level category of KILL, which provides a generic scenario, in which a KILLER causes a VICTIM to DIE (using some INSTRUMENT). Unlike slå ihjel, [V ihjel] expresses more specific instantiations of this scenario in accordance with the meaning of the verbs that appear in the construction, and thus refers to subordinate instantiations of the basic level KILL category. Whereas [V ihjel] is atomic and compositional, sla ihjel is non-compositional, as its internal structure cannot be analyzed into smaller symbolic units. This indicates that slå ihjel forms an entrenched communicatively specific subconstruction with the symbolic structure of [[slå ihjel]/[KILL]]. Furthermore, [[slå ihjel]/[KILL]] ranks quite high on Lipka \& Schmid's (1994) scale of idiomaticity, while [[V ihjel]/[ACTION > DEATH]] displays a much lower degree of idiomaticity. Given the fact that it serves a specific communicative purpose, [slå ihjel] is an item-specific construction in its own right which inherits some formal features from the central [V ihjel] construction, but which cannot be said to be on par with the instances of [V ihjel] in (9)-(25).

In addition to the semantic difference between [slä ihjel] and [V ihjel], the two also differ in terms of stress distribution. ${ }^{6}$ In [sla ihjel], the primary stress is placed on the second syllable in ihjel, while the main syllable of the verb receives primary stress in [V ihjel]. This difference is probably not arbitrary, but motivated by the specificity of content. Since [V ihjel] expresses subordinate instances of the KILL category, the verb specifies the nature of situation, and therefore, in terms of information prominence, it makes sense that it receives stress prominence so as to emphasize the specificity that defines the subordinate instance. $^{7}$ 
Given the semantic differences in levels of categorization and degree of idiomaticity and the formal differences, both in terms of lexical substantivity and stress distribution, it makes sense to argue that ['V ihjel] and [slå $i$ 'hjel] are two different constructions within the ihjel network.

\section{Reflexive objects}

In the three corpora, certain verbs, or types of verbs, in the ihjel-construction appear exclusively or significantly frequently with reflexive objects. In a complete inheritance approach, this would be of no consequence, since contextual factors are peripheral at best, but in a usagebased approach, in which linguistic competence is discourse-driven, such patterns must be taken into consideration.

Below are some examples of the ihjel-construction in reflexive syntactic contexts:

(32) Stop, stands, gem dog den djavelske tryllefløjte, før vi danser os ihjel.

Stop, hold it, put that damn magic flute away before we'll dance ourselves to death.

(33) De vil grine sig ihjel, konerne inde i byen.

They are going to laugh themselves to death, the women in town.

(34) Fem personer forsøgte i går at brcende sig ihjel inde på Den Himmelske Freds Plads $i$ Beijing.

Yesterday, five people tried to burn themselves to death on Tianmen Square in Beijing.

(35) Jeg knokler mig da halvt ihjel for dig. I work myself half to death for you.

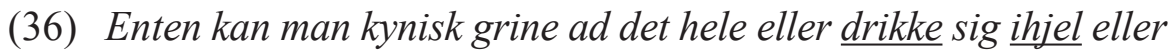
begge dele.

One can either laugh cynically at everything or drink oneself to death or do both. 


\section{Kim Ebensgaard Jensen}

There seem to be two different usage-patterns when it comes to the ihjel-construction and reflexive objects. The first pattern cannot be said to actually be a pattern, as it covers instances where the ihjel-construction just happens to appear with a reflexive object in order to express a self-directed action which happens to have fatal consequences. ${ }^{8}$ In such cases, there is no statistical significance in frequency of co-occurrence of verb and reflexive object. This is the case of (32)-(34). The second pattern, which applies to (35) and (36), includes instances where a specific verb, or a verb-class, co-occurs significantly frequently with a reflexive object, and the entire constellation may be argued to have a specific communicative function.

There are two semantic verb-classes whose members appear significantly frequently with reflexive objects in the ihjel-construction namely, verbs of effort and verbs of ingestion. These are likely to be item-class-specific subconstructions of the ihjel-construction which also have a preference for reflexive contexts understood such that this preference is entrenched as part of the linguistic competence pertaining to these subconstructions. In addition there are a number of individual verbs which appear either exclusively or significantly frequently with reflexive objects, such as gabe, grine, vokse, sejre, profilere and kede. While the two item-class-based usage patterns are literal in the sense that they express situations leading to literal deaths, these individual verbs are of a more metaphorical nature when appearing in the ihjelconstruction.

The two semantic verb-classes are more or less in violation of the principle of semantic compatibility since they do not express situations that will result in physical harm. Yet, some of the verbs within these categories display significant attraction to the ihjel-construction. Coercion is typically involved when there is semantic conflict between a lexeme and the construction it appears in. Coercion is "the general term for contextual reinterpretation" (Swart 2003:237), and coercion typically "occurs when there is a mismatch between the semantic types required by a given operator and the semantic type with which that operator is actually combined" (Francis \& Michaelis 2003:18). Coercion is thus a semantic type-shifting, or reconstrual, prompted by an atypical symbolic relation or an atypical context. In relation to the ihjel-construction, incongruous verbs are typically coerced into expressing situations that are more likely to have fatal results, and often additional information is added to what they typically express - information which is computable from neither ihjel nor the verb in question. 
Fatal attraction: inheritance and collostruction ...

7.1 Verbs of ingestion

Obviously in violation of the principle of semantic compatibility, drikke is nonetheless quite highly attracted to the ihjel-construction in all three corpora, with cede and spise being less attracted, yet displaying a statistically preference for reflexive objects. Below are some examples:

(37) Når jeg har drukket mig ihjel og er død og begravet, vil du se orme og alt muligt.

When I've drunk myself to death and am dead and buried, you'll see worms and all kinds of things.

(38) Selvom han i dag er en køn og slank dreng, kunne han spise sig ihjel, hvis han fik lov.

Even though he is a pretty and slim boy today, he could eat himself to death if allowed to.

(39) Navnet betyder Det Store Adegilde og mindede os om en femten år gammel fransk film af samme titel, hvor fire let aldrende ungkarle åd sig ihjel på en lang weekend.

The name means The Big Feast and reminded us of a fifteen years old French move with the same title, in which four slightly aging bachelors ate themselves to death while on an extended weekend.

Drikke, cede, and spise express specifications of the ingestion scenario which, as mentioned above, is incongruous with the ihjel-construction. However in the ihjel-construction, verbs of ingestion are coerced into expressing EXCESSIVE INGESTION which will lead to the DEATH of the INGESTOR. Thus, [VINGESTION $\mathrm{OBJ}_{\text {reflexive }}$ ihjel] seems to combine the specified INGESTION frame expressed by the verb in question with the ihjelconstruction through fusion with the participant roles of the reflexive transitive construction.

While this might, at first sight, look like just an instance of the transitive reflexive construction at play like in (34), there is an important semantic difference. In a case like (34), no coercion is involved, and no additional information is added to the verb other than the situation being a self-directed one. The EXCESS component is not directly derived from the elements in this instantiation of the ihjel-construction, but added via coercion.

Moreover, using a verb of ingestion with a non-reflexive object would be, if not ungrammatical, then at least questionable: 
(40) a. ?Fire let aldrende ungkarle åd den ihjel.

Four slightly aging bachelors ate it to death.

b. ?Fire let aldrende ungkarle drak det ihjel.

Four slightly aging bachelors drank it to death.

c. ?Fire let aldrende ungkarle spiste den ihjel.

Four slightly aging bachelors ate it to death.

It does indeed seem that verbs of ingestion (at least the three verbs that appear in the three corpora $)^{9}$ display specific patterns of behavior in terms of syntactic context. So, here, it would make sense to argue that $\left[\mathrm{V}^{\mathrm{INGESTION}} \mathrm{OBJ}_{\text {reflexive }}\right.$ ihjel] does form an item-class-specific subconstruction.

When comparing spise and cede, we see that cede is more attracted to the ihjel-construction than spise, the reason probably being a difference in degree of semantic compatibility between these verbs and the ihjel-construction. Spise expresses the basic level category of INGESTION of SOLID SUBSTANCES by HUMANS, whereas aede expresses INGESTION of SOLID SUBSTANCES by ANIMALS. When used with humans, aede often refers to a more gluttonous, less civilized and more animalistic, way of eating. Ade is thus a more 'dramatic' word than spise, and also implies large quantities of food, and the gluttonous eating and the amounts of food associated with cede, arguably makes cede more compatible with the ihjel-construction than a less dramatic verb like spise.

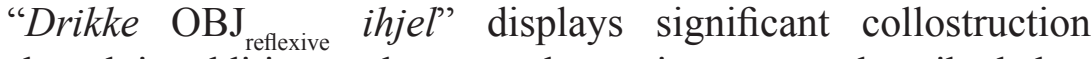
strength and, in addition to the general coercion pattern described above, it seems to serve an even more specific communicative function. The verb drikke itself expresses the generic situation of INGESTING any form of LIQUID SUBSTANCE, but it may also more specifically express the INGESTION OF ALCOHOL through conventional implicature. In the ihjelconstruction, this implicature gains primary salience, and drikke seems to exclusively express EXCESSIVE CONSUMPTION OF ALCOHOL. It is possible that the EXCESS component is inherited from the item-class-specific subconstruction discussed above. These factors point in the direction of [DRIKKE $\mathrm{OBJ}_{\text {reflexive }} i$ ihel] being an item-specific subconstruction of the ihjel-construction which inherits most of its form and content from the [V $\mathrm{V}^{\mathrm{INGESTION}} \mathrm{OBJ} \mathrm{Jeflexive}$ ihjel] subconstruction, but still serves a specific communicative function. 
Fatal attraction: inheritance and collostruction ...

7.2 Verbs of effort

The class of verbs dubbed verbs of effort includes verbs that refer to the process of working. In the ihjel-construction, verbs of effort primarily appear with reflexive objects.

(41) Det var det år, Ib Schønberg bukkede under for kraft efter i reali teten at have knoklet sig selv ihjel.

That was the year the Ib Schønberg gave in to cancer, in reality having worked himself to death.

(42) Han mener dog ikke, at de nye arbejdstidsregler vil føre til det rene anarki, hvor en gruppe danskere vil arbejde sig ihjel. He does not think, however, that the new rules for working hours will result in a state of pure anarchy in which a group of Danes will work themselves to death.

(43) Da vi var toet på den rendyrkede liberalisme, sled tusinder af arbejdere sig ihjel under umenneskelige forhold i byernes slum. When we were close to having pure Liberalism, thousands of workers worked themselves to death in the slums of the cities.

In the corpora, verbs of effort combined with ihjel invariably express the WORKING frame in which an AGENT WORKS on ACHIEVING a GOAL (using some SALIENT ENTITY Or INSTRUMENT). As with the verbs of ingestion, specificity versus generality in relation to level of categorization appears to have an influence on verb attraction to the ihjel-construction, which primarily attracts verbs that express HARD WORK rather than just basic level WORK - slide and knokle appear in Korpus 90 and Korpus 2000, ranking relatively high, whereas the basic level term arbejde only appears in Korpus 2000, ranking at 57 which is towards the bottom. This suggests again that specific and more dramatic verbs tend to be preferred over more generic and vague basic level ones in the ihjelconstruction.

\section{Metaphorical extensions}

Most of the instances of the ihjel-construction we have discussed so far are very much literal in the sense that the predicated situations result in the literal death of a participant. However, the ihjel-construction may also be metaphorically used to express situations which are conceptualized in terms of the content of the ihjel-construction. Such metaphorical 
extensions are not uncommon among constructions (Lakoff 1987:465). Consider the following examples:

(45) Denne sag kan bagatelliseres ihjel.

It is possible to trivialize this case "to death".

(46) Men enhver, der har prøvet at få sine koereste hjertebørn anmeldt ihjel, ved at overborenhed ikke proeger universitetsmiljøet.

Anyone who has had their darlings reviewed "to death" knows that forgiveness is not a characteristic of Academia.

(47) Pigen derimod analyserer og intellektualiserer det spcede forhold ihjel.

The girl, however, will analyze and intellectualize the new and fragile relationship "to death".

(48) De to selskaber var ved at konkurrere hinanden ihjel.

The two companies where about to compete each other "to death".

(49) Jeg tror, man kan producere sig selv ihjel.

I think it is possible to produce oneself "to death".

(50) Enhver god sag kan diskuteres ihjel.

Any good case can be discussed "to death".

(51) Kulturen er sneet inde $i$ velfcerd, sødet ihjel af pop, eller styret af underholdningsbranchen.

Culture is snowbound by welfare, sweetened "to death" by pop or controlled by the entertainment business.

All of the above examples express an ACTION CARRIED OUT IN EXCESS LEADING TO A METAPHORICAL DEATH. The ACTION is carried out to such an extent, by repetition or otherwise, that it influences the PATIENT as way that it is likened to DEATH and the PATIENT is likened to a VICTIM of KILLING.

Perhaps not surprisingly, the verbs that are used metaphorically in the ihjel-construction generally display low collostruction strength. This is to be expected, as it complies very well with the principle of semantic compatibility. It is possible that this pattern of metaphorical use of the ihjel-construction forms a conventional metaphorical extension

of the construction, thus serving as a subconstruction inheriting from 
the central construction through a metaphorical inheritance link (Goldberg 1995).

There are a few highly attracted verbs which are incongruous with the ihjel-construction, and which appear exclusively in metaphorical extension of the construction. They seem to inherit the EXCESS component from the general metaphorical extension construction, but, given that the verbs are so highly attracted to the construction, it is possible that they form item-specific subconstructions within the metaphorical extension of the ihjel-construction.

One such candidate is [kede $\mathrm{OBJ}_{\text {(reflexive) }}$ ihjel], which inherits the EXCESS component, but not the metaphorical DEATH facet as such:

Nu har de kedet folk ihjel $i$ århundreder.

They have bored people to death for centuries now.

(53) Hvad gør så en intellektuel, når det er noget lort at flyve i concorde og man keder sig ihjel hos Shell?

What, then, is an intellectual supposed to do when flying on a concorde sucks, and one is bored to death at Shell's?

This configuration expresses a scenario in which an EXPERIENCER has an EXPERIENCE of some STIMULUS, the EXPERIENCE itself being one of BOREDOM, and thus it combines this BORE scenario with semantic components of the ihjel-frame. Interestingly, [SUBJ kede OBJ ihjel] appears more frequently with reflexive objects than non-reflexive ones, with a frequency of occurrence of $87 \%$ versus $17 \%$. This suggests that, perhaps, a usage-pattern is emerging in which reflexive objects are becoming an integrated part of the linguistic knowledge pertaining to [kede OBJ ihjel]. Yet, it is likely that the preference for reflexive objects is inherited from one of the senses of kede, which, when appearing with a reflexive, describes the EXPERIENCER'S EXPERIENCE of BOREDOM as in (53) above. ${ }^{10}$ As mentioned above, death is not the outcome of the situation, and, unlike in examples (45)-(51) where a participant clearly suffers some metaphorical DEATH, the EXPERIENCER cannot really be said to die even metaphorically here. It seems that only the EXCESS component from the metaphorical extension applies here. So, the EXPERIENCER does not necessarily die from being bored. Rather, the expression metaphorically conveys a very high degree of boredom.

Another possible subconstruction within the metaphorical extension is [TIE ihjel], which like [kede ihjel] expresses high collostruction strength. Here are some examples: 
(54) Han skulle ties ihjel.

He should be hushed to death. $=$ He should have been forgotten/ ignored by not being mentioned.

(55) Og så er der alle de forhold, der er blevet tiet ihjel. And then there are all those issues that have been hushed to death. $=$ And then there are all those issues that have not been mentioned and which people are oblivious of.

(56) Fordrivelsen som helhed skulle have varet tiet ihjel.

The expulsion as a whole should have been hushed to death. = The expulsion as a whole should have remained unknown by not being mentioned.

Gabe, grine, vokse, sejre, and profilere, which I mentioned above, along with the verbs in examples (41)-(51), are not likely candidates for itemspecific metaphorical extensions due to the low degrees of general attraction. However, it is possible that a number of these verbs form itemclass-specific metaphorical extensions within the ihjel-network provided that it is, indeed, possible to identify enough semantic overlaps to establish classes. For instance, gabe and grine as well as vokse all predicate more or less unvolitional one-participant situations. However, it is a matter of debate whether this is enough to argue that they belong to the same semantic category.

\section{Conclusion}

The present study is by no means any sort of exhaustive account of the ihjel-construction; nor is it intended as such. If anything, it is more like the first fumbling steps towards a usage-based constructionist account of the phenomenon. While a number of usage-patterns have been identified in the corpora, and proposed as potential subconstructions, the most important observation in this study is perhaps the complexity of the ihjel-construction in that what formally appears to be a simple twoitem phrasal verb covers several different patterns of use.

By far, most of the observed facets of ihjel could not have been accounted for in a construction grammar based on complete inheritance, since complete inheritance networks are flat and symmetrical in structure, meaning that each and every instance inherits its features directly from the central constructional configuration, the consequences of which are 1) there is no room for subconstructions in the constructional network because theres is bound to be some recundancy between sub- 
constructions and the central abstract construction, and 2) many usagepatterns will have to be left out, because, without subconstructions, all information is stored in the central abstract construction, which cannot contain conflicting or differing features which then will have to be filtered out. This would result in incomplete descriptions of many constructions, including the ihjel-construction.

The collostructional analyses of the ihjel-construction indicate that its ontological status is much more complex than what a complete inheritance model could cope with, as it were. Just the fact that the verbs that appear in the construction display differing degrees of attraction shows that its instances are not symmetrically ordered. Some individial verbs, like slå, are highly attracted to the construction, forming item-specific subconstructions, while others form clusters, or classes, of semantic-types-based item-class-specific subconstructions, many of which display their own patterns of behavior. And serve their own specific communicative functions.

As mentioned above, while the results of this investigation are far from exhaustive, these observations will, hopehully, pave the way, so to speak, for future usage-based constructionist studies into the seemingly simple yet very complex two-element construction.

\section{Notes}

1 See the glossary of verbs in the appendix for English glosses of Danish verbs referred to in this paper.

2 The brackets before the slash indicate the form, while the ones after the slash indicate the content. The slash itself represents the symbolic relation between form and meaning.

3 I used Gries' (2007) coll.analysis 3.2, which is a software program specifically designed for collostruction analysis, to calculate the collostruction strengths in all three corpora.

4 An item-specific construction or subconstruction is one which is defined by the occurrence of one lexically substantive item, which an item-classspecific construction is one which is defined by the occurrence of a limited set, or class, of items.

5 Note that ligge + ihjel is often listed in dictionaries as a lexical unit which refers to the situation of a female animal crushing her offspring to death while sleeping. Ligge is not saliently attracted to ihjel in any of the three corpora used for this study. This does not mean, however, that the dictionaries are wrong. The corpora used in this study are general corpora, but ligge ihjel is a specific farming term and is probably much more productive in varieties of Danish pertaining to farming and agriculture. My guess is that ligge ihjel would figure much more prominently in a corpus based on these varieties of Danish. 


\section{Kim Ebensgaard Jensen}

6 Thanks to Ken Farø for pointing this out.

7 Interestingly, [køre ihjel] seems to follow the same stress distributional pattern as [slå ihjel], which may indicate that [køre ihjel] displays subconstructional salience.

8 This presupposes, of course, that we accept that the main function of [SUBJ $\left.\mathrm{V} \mathrm{OBJ}_{\text {reflexive }}\right]$ is to predicate a SELF-DIRECTED SITUATION in which the AGENT and the PATIENT are realized by the same entity. The reflexive construction is, technically, an argument structure construction whose parent is the general transitive construction.

9 Whether or not the use of verbs of ingestion in the ihjel-construction exceeds these three verbs is a question that requires more empirical research to be answered.

${ }^{10}$ If that is indeed the case then we are dealing with inheritance from what Boas (2003) calls a miniconstruction, which is the argument structure construction associated with the specific sense of a polysemous verb.

\section{References}

Bergen, Benjamin K \& Nancy C. Chang (2005). Embodied construction grammar in simulation-based language understanding. In: Jan-Ola Östman \& Mirjam Fried (eds.) Construction Grammar(s): Cognitive and Crosslanguage Dimensions, Amsterdam: John Benjamins:145-90.

Biber, Douglas (2000). Investigating language use through corpus-based analyses of association patterns. In: Barlow, Michael \& Suzanne Kemmer (eds.) Usage-Based Models of Language, Stanford: Stanford University Press:287-313.

Biber, Douglas, Susan Conrad \& Randi Reppen (1998). Corpus Linguistics: Investigating Language Structure and Use, Cambridge: Cambridge University Press.

Bick, Eckhard (2005). CorpusEye: et brugervenligt web-interface for grammatisk opmærkede korpora. In: Peter Widell \& Mette Kunøe (red.) 10. Møde om Udforskningen af Dansk Sprog 7.-8. okt. 2004, Proceedings. Aarhus: Aarhus University Press:46-57.

Boas, Hans (2003). A Constructional Approach to Resultatives. Stanford: Stanford University Press.

Croft, William A. (2000). Explaining Language Change: An Evolutionary Approach, London: Longman.

Croft, William A. (2001). Radical Construction Grammar: Syntactic Theory in a Typological Perspective, Oxford: Oxford University Press.

Croft, William A. (2003). Lexical rules vs. constructions: a false dichotomy. In: Cuyckens, H., T. Berg, R Dirven \& K. Panther (eds.) Motivation in Language: Studies in Honour of Günter Radden, Amsterdam: John Benjamins:49-68. 
Fatal attraction: inheritance and collostruction ...

Croft, William A. (2005). Logical and typological arguments for Radical Construction Grammar. In: Östman, Jan-Ola (ed.) Construction Grammars: Cognitive Grounding and Theoretical Extensions, Amsterdam: John Benjamins:273-314.

Croft, William A. \& D.A. Cruse (2004). Cognitive Linguistics, Cambridge: Cambridge University Press.

Fillmore, Charles J., Paul Kay \& Mary Catherine O'Connor (1988). Regularity and idiomaticity in grammatical constructions: the case of let alone, Language, 64 (1988):501-39.

Francis, Elaine J. \& Laura A. Michaelis (2003). Mismatch: a crucible for linguistic theory. In: Francis, Elaine J., Laura A. Michaelis (eds.) Mismatch: Form-Function Incongruity and the Architecture of Grammar, Stanford, CA: Stanford University Press:1-27.

Goldberg, Adele E. (1995). Constructions: A Construction Grammar Approach to Argument Structure, Chicago: University of Chicago Press.

Gries, Stefan Th. (2007). Coll.analysis 3.2., R-based software.

Gries, Stefan Th. \& Anatol Stefanowitsch (2004). Covarying collemes in the into-causative. In: Achard, Michael, Suzanne Kemmer (eds.) Language, Culture, and Mind, Stanford, CA: Stanford University Press:225-236.

Hopper, Paul J. (1998). Emergent grammar. In: Michael Tomasello (ed.) The New Psychology of Language: Cognitive and Functional Approaches to Language Structure, Mahwah, NJ: Lawrence Erlbaum:155-175.

Kemmer, Suzanne \& Michael Barlow (2000). Introduction: a usage-based conception of language. In: Barlow, Michael, Suzanne Kemmer (eds.) Usage-Based Models of Language, Stanford: Stanford University Press:vii-xxviii.

Lakoff, George (1977). Linguistic gestalts, Chicago Linguistics Society 13, Chicago: CSL:236-87.

Lakoff, George (1987). Women, Fire and Dangerous Things: What Categories Reveal about the Mind, Chicago: Chicago University Press.

Langacker, Ronald W. (1987). Foundations of Cognitive Grammar. Vol. 1: Theoretical Prerequisites, Stanford, CA: Stanford University Press.

Langacker, Ronald W. (1991). Foundations of Cognitive Grammar. Vol. 2: Descriptive Application, Stanford, CA: Stanford University Press.

Lipka, Leonhard, Hans-Jörg Schmid (1994). "To begin with: degrees of idiomaticity, textual functions and pragmatic exploitations of a fixed expression", Zeitschrift für Anglistik und Amerikanistik, 42 (1994):6-15.

Michaelis, Laura A. (1998). Aspectual Grammar and Past-time Reference, London: Routledge.

ODS = Det Danske Sprog- og Litteraturselskab (2007 [2005-2007]). Ordbog Over Det Danske Sprog, [Online] (http://ordnet.dk/ods/)

Swart, Henrietta de (2003). Coercion in a cross-linguistic theory of aspect. In: Elaine J. Francis \& Laura A. Michaelis (eds.) Mismatch: Form-Function 
Incongruity and the Architecture of Grammar, Stanford, CA: Stanford University Press:231-58.

Stefanowitsch, Anatol \& Stefan Th. Gries (2003). "Collostructions: investigating the interaction between words and constructions", International Journal of Corpus Linguistics 8 (2005):2-43.

Stefanowitsch, Anatol, Stefan Th. Gries (2005). "Covarying collexemes", Corpus Linguistics and the Linguistic Theory 1 (2005):1-43.

Tomasello, Michael (2003). Constructing a Language: A Usage-Based Theory of Language Acquisition, Cambridge, MA: Havard University Press.

VISL (2008 [1996]). VISL: Visual Interactive Syntax Learning. [Online]. $<$ http://visl.sdu.dk $>$

Appendix: Glossary of verbs

$\begin{array}{ll}\text { analysere = 'analyze' } & \text { hakke = 'peck' } \\ \text { anmelde = 'review' } & \text { hygge = 'have a nice time' } \\ \text { arbejde = 'work' } & \text { intellektualisere = 'intellectualize' } \\ \text { bagatellisere = 'trivialize' } & \text { jokke = 'stomp' } \\ \text { banke = 'knock'/'beat up' } & \text { kede = 'bore' } \\ \text { behandle = 'treat' } & \text { klemme = 'squeeze'/'crush' } \\ \text { beskatte = 'tax' } & \text { klippe = 'cut' } \\ \text { bide = 'bite' } & \text { knokle = 'work hard' } \\ \text { blende = 'blend' } & \text { koge = 'boil' } \\ \text { brænde = 'burn' } & \text { konkurrere = 'compete' } \\ \text { danse = 'danse' } & \text { kvæle = 'strangle'/'suffocate' } \\ \text { diskutere = 'discuss' } & \text { køre = 'drive' } \\ \text { dolke = 'stab' } & \text { ligge = 'lie' } \\ \text { drikke = 'drink' } & \text { lure = 'peep' } \\ \text { elske = 'love' } & \text { mase = 'crush' } \\ \text { fortie = 'silence' } & \text { pine = 'torture' } \\ \text { fryse = 'freeze' } & \text { piske = 'whip' } \\ \text { gabe = 'yawn' } & \text { producere = 'produce' } \\ \text { gasse = 'gas' } & \text { profilere = 'profile' } \\ \text { grine = 'laugh' } & \text { prygle = 'beat up' } \\ \text { gå = 'walk' } & \text { riste = 'roast' }\end{array}$

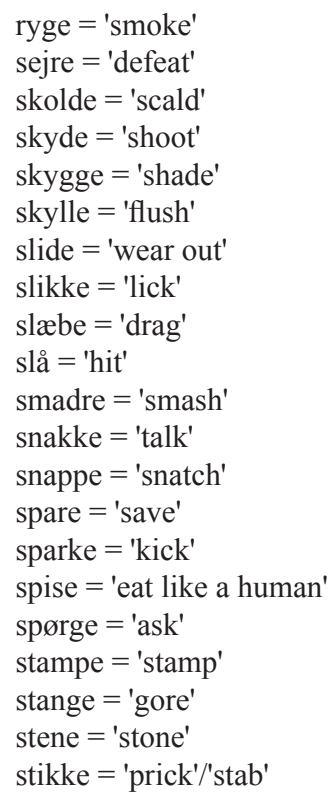

\author{
sulte $=$ 'starve' \\ svede $=$ 'sweat' \\ synge $=$ 'sing' \\ søde = 'sweeten' \\ sørge $=$ 'mourn' \\ tale $=$ 'speak' \\ tie $=$ 'remain silent' \\ tortere $=$ 'torture' \\ trampe $=$ 'stamp'/'stomp' \\ træde $=$ 'step'/'tread' \\ træne $=$ 'train' \\ tvivle $=$ 'doubt' \\ tærske $=$ 'thrash' \\ tæske $=$ 'beat up' \\ tæve = 'beat up' \\ tørste $=$ 'thirst' \\ udpege $=$ 'point out' \\ underholde $=$ 'entertain' \\ visne $=$ 'wither' \\ vokse $=$ 'grow' \\ $æ$ de $=$ 'eat like an animal'
}

Kim Ebensgaard Jensen

Institut for Kultur og Globale Studier

Aalborg Universitet

kim@cgs.aau.dk 